\title{
Dissemination of triactinomyxons (Myxozoa) via oligochaetes used as live food for aquarium fishes
}

\author{
Sascha L. Hallett ${ }^{1,3}$, Stephen D. Atkinson ${ }^{1,3}$, Christer Erséus ${ }^{2,4}{ }^{,}$Mansour El-Matbouli ${ }^{1, *}$ \\ ${ }^{1}$ Institute of Zoology, Fish Biology and Fish Diseases, University of Munich, Kaulbachstrasse 37, 80539 Munich, Germany \\ ${ }^{2}$ Department of Invertebrate Zoology, Swedish Museum of Natural History, Box 50007, 10405 Stockholm, Sweden \\ ${ }^{3}$ Present address: Center for Fish Disease Research, Department of Microbiology, Oregon State University, Nash Hall 220, \\ Corvallis, Oregon 97331, USA \\ ${ }^{4}$ Present address: Department of Zoology, Gothenburg University, Box 463, 40530 Gothenburg, Sweden
}

\begin{abstract}
Freshwater 'tubifex' oligochaetes sold as live food for aquarium fishes were purchased from several pet shops in Munich, Germany, over a 1 yr period (March 2001 to February 2002). These samples were screened for parasitic infections of actinosporean myxozoans to gauge the possibility of parasite dispersal via this route. Of 7 samples, 6 contained infected oligochaetes; waterborne spores were present in 5 samples at the time of purchase. In the laboratory, 12 different types of actinosporeans were released by the oligochaetes. These could be assigned to 4 collective groups: triactinomyxon, aurantiactinomyxon, raabeia and hexactinomyxon; 4 novel triactinomyxons are described herein, a fifth triactinomyxon has been described earlier. Phenotypic descriptions of the spores are accompanied by molecular sequence data (18S rDNA). Descriptions of the other actinosporean types appear elsewhere. The worms sold as 'tubifex' originated from eastern European countries and were identified as a mix of Tubifex tubifex, Limnodrilus hoffmeisteri and L. udekemianus. Sale of live worms (and their accompanying parasite load) has clearly the potential to facilitate introduction both of parasites and suitable hosts to new areas.
\end{abstract}

KEY WORDS: Actinosporean · Myxozoa · Triactinomyxon · Oligochaete $\cdot$ Parasite dissemination · Pet shop

\section{INTRODUCTION}

The freshwater tubificid oligochaete Tubifex tubifex Müller, 1774, is a cosmopolitan species, which occurs in a wide range of habitats, from polluted to pristine (Kathman \& Brinkhurst 1998). In these ecosystems the worms are a food source for a range of organisms including crustaceans, fishes, insects and other annelids (Gilbert \& Granath 2003). Not surprisingly, T. tubifex is the main constituent of 'tubifex' worms sold as live food at pet shops, principally for aquarium fishes. Other tubificid worms, however, may be included in the 'tubifex' mix, such as Limnodrilus hoffmeisteri Claparède, 1862, another widespread species and the most common tubificid in many habitats, especially polluted sites (Kathman \& Brinkhurst 1998).
Both of these oligochaete species are hosts for a number of parasites including cestodes, flagellates, microsporeans and myxozoans (Raftos \& Cooper 1990). Indeed, live oligochaetes have long been known as vectors for the introduction of pathogens into aquaria; hence, many fish food companies now sell irradiated and/or freeze-dried products to eliminate these problems. However, both live and frozen oligochaete worms continue to be in demand for fish species that require live prey and some that need live food to aid conditioning for successful breeding.

More than 30 actinosporean myxozoans from at least 7 collective groups (some $20 \%$ of all described species) have been recorded from Tubifex tubifex, some of which have been shown to alternate with a myxosporean stage in a fish host to complete their life cycle 
(Kent et al. 2001). The discovery of actinosporeaninfected oligochaetes in shipments of 'tubifex' worms imported from eastern Europe into the United States as food for aquarium fishes (Lowers et al. 2000, Lowers \& Bartholomew 2003) prompted us, based in central Europe, to examine locally sold worms for similar infections. From 7 samples containing 2000 to 10000 oligochaetes each, we identified 12 different types of actinosporeans representing 4 collective groups: triactinomyxon, aurantiactinomyxon, raabeia and hexactinomyxon. Herein, we document 5 triactinomyxons, 4 of which are novel. All phenotypic descriptions are accompanied by $18 \mathrm{~S}$ rDNA molecular sequence data. Descriptions of the other actinosporean types have appeared in separate publications (Hallett et al. 2003, 2004).

\section{MATERIALS AND METHODS}

Isolation of spores. Samples containing 2000 to 10000 live 'tubifex' oligochaetes were purchased from 3 Munich pet shops on 7 occasions: 13 March 2001 (Sample D1); 28 March 2001 (MW); 22 June 2001 (D2); 18 July 2001 (D3); 8 August 2001 (D4); 15 February 2002 (AC1); and 28 February 2002 (AC2). The water associated with the oligochaetes was filtered through a $20 \mu \mathrm{m}$ mesh sieve and the retained material washed into a small petri dish and examined for the presence of free-floating actinosporeans using a Zeiss Axiovert 25 inverted microscope under phase contrast. When suspended spores were observed, the worm sample was washed well with fresh tap water, subdivided into 5 to 10 smaller groups in plastic containers, and covered with fresh tap water. The following day, water from each container was filtered separately and examined for actinosporeans. Positive samples were further subdivided, then re-examined on subsequent days. Worms were subdivided until approximately 100 to 200 worms remained per positive sample; they were then placed individually into wells of a cell-well plate. The wells were examined under a dissection microscope over the following several days until all releasing individuals were determined.

Spores from positive wells were pipetted onto a glass microscope slide and measured under a coverslip using the aforementioned inverted microscope. Spores were also pipetted onto slides, air-dried, fixed, then stained with either Giemsa or Diff-Quik. Spores are described herein in accordance with the guidelines of Lom et al. (1997) though we use 'spore axis' introduced by Xiao \& Desser (1998a) rather than 'total length', and 'germ cell' instead of 'daughter cell'. Further, the largest span between the processes was not measured as we consider this metric unreliable due to the inherent variability in position of triactinomyxon processes when compressed under a coverslip. Measurements of freshly released spores from individual oligochaetes were taken using a calibrated eyepiece micrometer.

Molecular analysis. DNA extraction and amplification: Triactinomyxon spores were collected for DNA extraction by placing host oligochaetes individually in microcentrifuge tubes in a small amount of fresh tapwater for 24 to $48 \mathrm{~h}$, after which time the worm was removed and the spore sample either frozen or processed immediately. DNA was extracted using the QIAamp DNA Mini Kit-Tissue protocol (QIAGEN) according to the manufacturer's instructions, except that samples were resuspended in $50 \mu$ distilled water (DW). Triactinomyxon spores of Myxobolus cerebralis Höfer, 1903 collected from laboratory-infected Tubifex tubifex were included as a reference sample.

Initial amplification of the $18 \mathrm{~S}$ small subunit ribosomal DNA gene (18S rDNA) was achieved using the primers 18e and 18g (Hillis \& Dixon 1991); $20 \mu \mathrm{l}$ reactions contained $5 \mu \mathrm{l}$ extracted genomic DNA, $4 \mathrm{nmol}$ dNTPs, 10 pmol each primer, $2 \mu$ l0X Taq buffer, $2.5 \mathrm{mM} \mathrm{MgCl}_{2}, 1$ unit (U) Taq polymerase and DW. The PCR cycle profile was performed in either an Eppendorf Mastercycler Gradient (Eppendorf-Netheler-Hinz) or Primus V1.01 (MWG-Biotech) machine, and consisted of an initial denaturation step of $95^{\circ} \mathrm{C}$ for $2 \mathrm{~min}$ followed by the addition of the Taq, and followed by 30 cycles of $95^{\circ} \mathrm{C}$ for $1 \mathrm{~min}, 55^{\circ} \mathrm{C}$ for $30 \mathrm{~s}, 72^{\circ} \mathrm{C}$ for $1 \mathrm{~min}$, finishing with 1 cycle of $95^{\circ} \mathrm{C}$ for $1 \mathrm{~min}, 55^{\circ} \mathrm{C}$ for $30 \mathrm{~s}$, $72^{\circ} \mathrm{C}$ for $7 \mathrm{~min}$, with a terminal rest at $6^{\circ} \mathrm{C}$. The resultant PCR products were combined with gel-loading buffer and visualised in a $0.9 \%$ agarose tris-acetateEDTA buffer (TAE) gel stained with $7.5 \%$ ethidium bromide alongside a 100 bp DNA ladder (GIBCO BRL, Life Technologies) using a CN-TFX darkroom with UV-transilluminator TFX-20 (Itf-Labortechnik) and a digital image captured using BioCapt V.97.

Riboprint analysis: A PCR-restriction fragment length polymorphism analysis was conducted part way through the study to gauge the number of triactinomyxon types discernible by molecular data. A nested PCR comprising $2 \times 20 \mu \mathrm{l}$ reactions per sample, $1 \mu \mathrm{l}$ of the first-round PCR product and the primers MYX1f (Hallett \& Diamant 2001) and MX3 (Andree et al. 1998) was performed to generate enough template for use in the digest. Each pair of products was pooled and purified using the QIAquick PCR purification kit (QIAGEN) as per the manufacturer's instructions and eluted in $50 \mu \mathrm{l}$ DW; the double-standed DNA (dsDNA) concentration was measured using an Eppendorf BioPhotometer 6131.

We digested $1 \mu \mathrm{g}$ of DNA (PCR product) of each purified triactinomyxon separately with $10 \mathrm{U}$ of 2 different endonucleases, Dde I and Hha I (New England BioLabs) and their corresponding buffer, and incu- 
bated these at $37^{\circ} \mathrm{C}$ for $1.5 \mathrm{~h}$. The resultant digest products were visualised in a $1.5 \%$ agarose TAE gel containing $7.5 \%$ ethidium bromide, run alongside a $100 \mathrm{bp}$ ladder, and visualised as above.

Sequencing: Combinations of paired sequencing primers were tested on $0.5 \mu \mathrm{l}$ of the $18 \mathrm{e} / 18 \mathrm{~g}$ template in $20 \mu \mathrm{l}$ reactions to assess their suitability. A 5' end fragment of $\sim 1000 \mathrm{bp}$ in length was produced using the nested primers MYX1f and ACT1r (Hallett \& Diamant 2001) in separate $5 \times 20 \mu$ reactions using 0.2 to $0.5 \mu \mathrm{l}$ PCR product per reaction. All samples (except Tri type 2) were sequenced with those primers as well as with ACT1f and ACT1fr (Hallett \& Diamant 2001); Tri type 2 was sequenced only with ACT1fr. The 3' end was more variable among the samples and therefore different templates were sequenced with different primers depending on their success in the initial trial reactions. These included ACT3f (Hallett \& Diamant 2001), ACT2fr (Hallett et al. 2003), ALL1f (Hallett et al. 2002), MX3, ALL1r (Hallett et al. 2002), and 18g. PCR products were purified, the dsDNA concentration measured, and the samples sent to Sequence Laboratories Göttingen for cycle-sequencing in both directions.

The various forward and reverse segments of sequence generated for each triactinomyxon were aligned manually in BioEdit (Hall 1999) and ambiguous bases clarified using corresponding ABI chromatograms (where a base remained indistinct an $\mathrm{N}$ was designated). The complete sequence was submitted to GenBank (Accession Nos. AY495704 to 7). A standard nucleotide-nucleotide BLAST (blastn) search was conducted (www.ncbi.nlm.nih.gov/BLAST; Altschul et al. 1997).

Identification of host oligochaete. Infected worms were kept alive for up to 12 mo to monitor spore release. Worms were placed individually in plastic vials containing sterilised sediment and fresh water, and fed once a week with commercially available spirulina algae flakes. For identification, the anterior third of each worm was fixed in Bouin's solution for 3 to $24 \mathrm{~h}$, then transferred to $70 \%$ ethanol. The material was stained in an alcoholic paracarmine solution, differentiated in acid alcohol, dehydrated and cleared through an ethanol-xylene series, and finally mounted in Canada balsam. Oligochaetes were identified using characteristics summarised in several standard keys of freshwater Oligochaeta (e.g. Kathman \& Brinkhurst 1998, Timm 1999).

Site of infection. The posterior region of the host was cut into small pieces (1 to $2 \mathrm{~mm}$ long), fixed in $6.25 \%$ glutaraldehyde overnight, and then transferred to phosphate buffer ( $\mathrm{pH}$ 7.2). They were then post-fixed in $1 \%$ osmium tetroxide for $2 \mathrm{~h}$, washed, dehydrated in a graded acetone series, and embedded in Epon. Semithin sections were stained with Toluidine blue.

\section{RESULTS}

We screened 7 samples of 'tubifex' worms from 3 pet shops in Munich over a 1 yr period from March 2001 to February 2002. Worms were sold in a small amount of water which (from 5 samples) contained waterborne actinosporean spores (phylum Myxozoa Grassé, 1970; class Myxosporea Bütschli, 1881; actinosporean forms, Kent et al. 1994). A total of 6 of the 7 samples (representing all pet shops) released spores in the laboratory. We identified 12 types of actinosporeans, of which 10 appear to be novel; these could be assigned to 4 collective groups: triactinomyxon (5 types), aurantiactinomyxon (2), raabeia (3) and hexactinomyxon (2). We identified 3 species of tubificids (Tubifex tubifex, Limnodrilus hoffmeisteri and L. udekemianus) as the host oligochaetes. Only 1 pet shop was forthcoming with details of the origin of their oligochaete stocks: Samples D1 to 4 were from Romania and Hungary.

Actinosporeans of the collective group triactinomyxon were most prevalent and speciose: 5 forms were identified, which were released from 50 infected hosts (all Tubifex tubifex). All spores were of the characteristic anchor shape: they possessed a spore axis which comprised anteriorly a spore body with sporoplasm containing germ cells and 3 polar capsules located at its apex, all encompassed by 3 valve cells which divided posteriorally into 3 caudal processes (which inflated upon contact with water).

The spores we isolated were compared with descriptions of other triactinomyxons (54 types) in the literature-Marquès (1984: 8 types, excluding incomplete record of Tubifex petri Georgevitch, 1940); Roubal et al. (1997: 1 type); El-Mansy et al. (1998b, c: 9 types); Xiao \& Desser (1998a: 6 types); Hallett et al. (2001: 2 types); Rácz \& Timm (2002: 1 type); Székely et al. (2002b: 2 types); Oumouna et al. (2003: 4 types); Lowers \& Bartholomew (2003: 7 types) - including those known to be an alternate stage of a fish myxosporean (Wolf \& Markiw 1984, El-Matbouli \& Hoffmann 1989, 1993, 1998, Kent et al. 1993, El-Mansy \& Molnár 1997a,b, El-Mansy et al. 1998a, Székely et al. 1999, 2002a, Eszterbauer et al. 2000). The 'triactinomyxons' recorded by El-Mansy (2001) were not included in comparisons since these have been subsequently transferred to a different collective group, Pseudotriactinomyxon (see Hallett et al. 2003).

For 12 of these, 18S rDNA sequence data was available in GenBank: Myxobolus arcticus (AF085176); M. bramae (AF085177); M. cerebralis (U96493); $M$. drjagini (AF085170); $M$. hungaricus (AF448444); M. macrocapsularis (AF507969); $M$. portucalensis (AF085182); M. pseudodispar (AF380145); Triactinomyxon C (AF378350); Triactinomyxon F (AF378351); Triactinomyxon ignotum (AF378349); and Triactinomyxon sp. (AF306792). 


\section{DESCRIPTIONS}

\section{Triactinomyxon type 1 nov. $n=19$ (Figs. $1 \& 2$ )}

Reference material. Spore possesses spore body, style and 3 caudal processes. Spore body with sporoplasm, barrel-shaped, contains either 30 or 32 germ cells and 3 prominent, pyriform, polar capsules, positioned apically; 3 valve cells, fused, surround polar capsules and sporoplasm and continue beneath this spore body complex to form an elongate style, which narrows to base where valve cells diverge to each form an elongate caudal process that curves slightly upwards or downwards and tapers to a point. Processes approximately equal in length; valve-cell nuclei one-third to two-thirds down length of process, diameter $2.6 \mu \mathrm{m}$ (see Table 1 for complete morphometrics).

Host of reference material. Tubifex tubifex.

Site in host. Intercellular in intestinal epithelium.

Source of material. Pet shop (Sample MW), Munich (28 March 2001).

Specimens deposited. Giemsa and Diff-Quik slides of air-dried spores deposited in the Queensland Museum, Brisbane, Australia, Accession Nos. G464761 and G464762 (however, specimens are not given type status in the sense of the International Code of Zoological Nomenclature).
Remarks. Although the oligochaete sample was obtained in March, spores were not detected in the filtrate until June. The single host worm continued to release spores for the next 12 mo until the end of the study in June 2002. A second sample acquired 11 mo later from a different pet shop (Sample AC 1, 15 February 2002) contained 2 Tubifex tubifex that released the same parasite (Fig. 2b,c) (Tri 1b,c); the morphometrics of both exemplars are given in Table 1. The distal quarter of each caudal process is often so finely tapered that it easily deforms. Although processes of individual spores appear approximately equal in length, the differences in length of the processes across all spores measured ranged from 3 to $39 \mu \mathrm{m}$ ( 0 to $18 \mu \mathrm{m}$ for Tri $1 \mathrm{~b}$ and 5 to $21 \mu \mathrm{m}$ for Tri $1 \mathrm{c}$ ). Spores were observed with either 30 or 32 germ cells.

Molecular data. The $18 \mathrm{~S}$ rDNA of spores from the 3 hosts was partially sequenced: Tri 1a generated 1607 bp (GenBank Accession No. AY495704), Tri 1b $1603 \mathrm{bp}$ and Tri 1c 335 bp. All 3 exemplars are identical over the 335 bp (comparison of this region with that of 13 other triactinomyxons in a previous study [Hallett et al. 2004] revealed 59.2 to $96.9 \%$ similarity). Tri 1a and $1 \mathrm{~b}$ have 2 to 5 base differences over 1595 bp (99.7 to $99.9 \%$ similar). A sequence-identity matrix of the 5 triactinomyxons described herein was constructed in BioEdit (Hall 1999) and showed that Triactinomyxon type 1 is most similar to Triactinomyxon type 4 (98.8\%)

Fig. 1. Triactinomyxon type 1 nov. (a) Line drawing; (b) oligochaete with freshly released spores. (c) Giemsa-stained air-dried spore highlighting germ cells and polar capsules; (d) compressed spore body showing germ cell nuclei
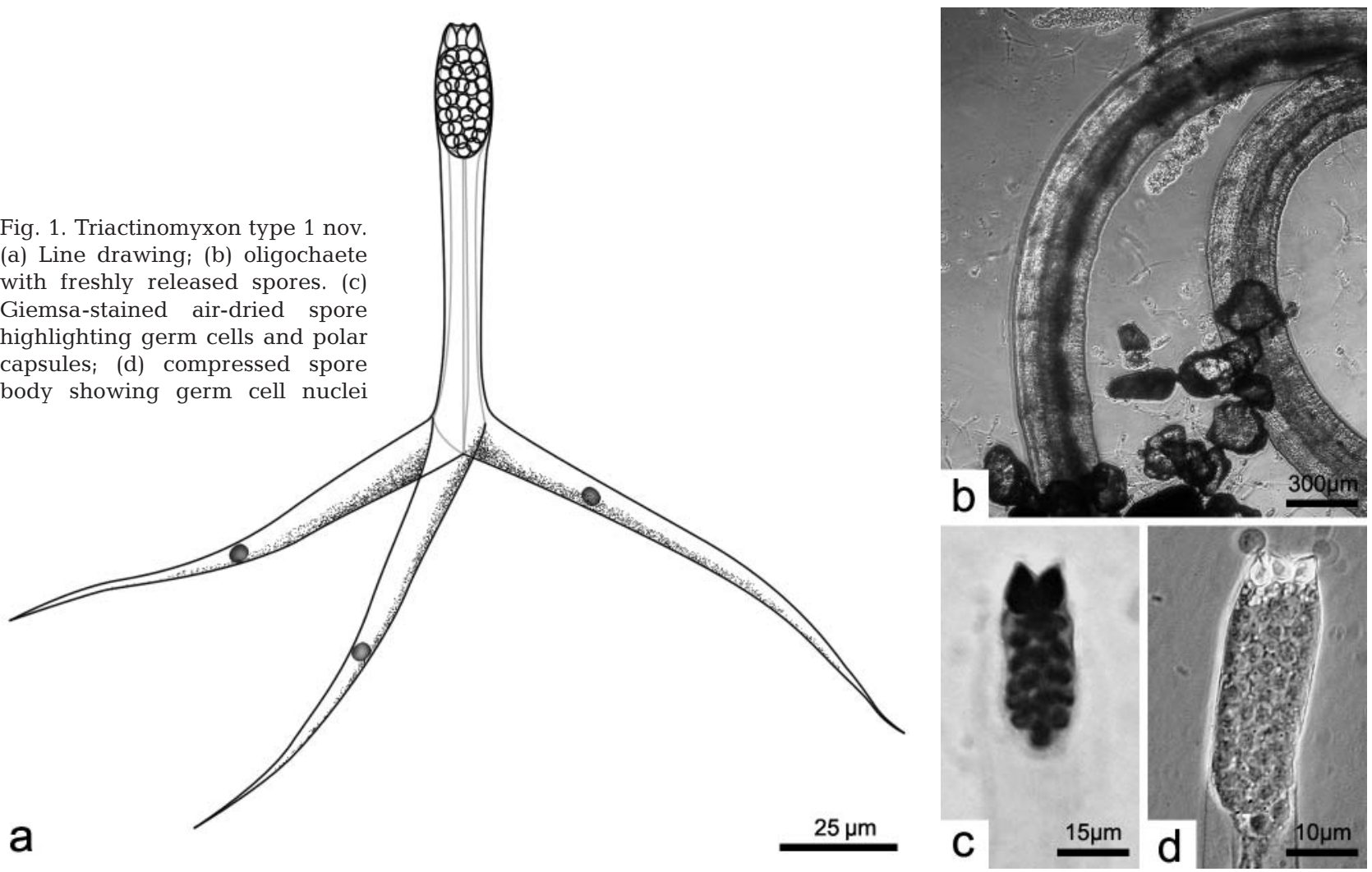

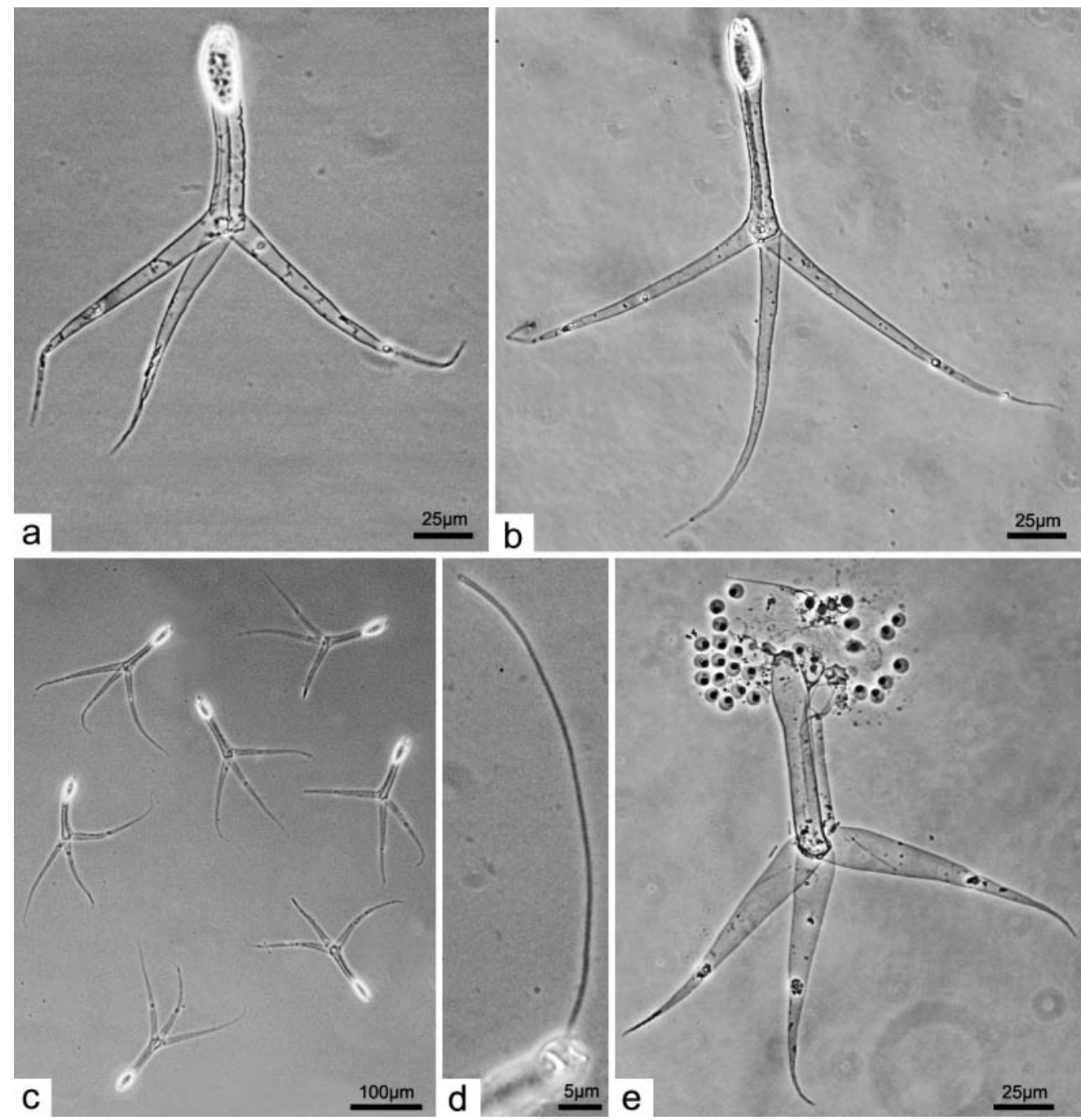

Fig. 2. Triactinomyxon type 1 nov. Photomicrographs of fresh, unstained preparations under coverslip. (a) Mature waterborne spore of reference sample (Tri 1a: see Table 1). Note degree of tapering of caudal processes. (b) Waterborne spore released from the second oligochaete host (Tri 1b). (c) Waterborne spores released from third oligochaete host (Tri 1c). (d) Fully extruded polar filament showing typical thickening at end. (e) Compressed Tri 1a spore whose valve cells have separated at the spore apex and released the contents of the spore body with germ cells and their nuclei now more clearly defined

over $1432 \mathrm{bp}$. Comparison of the $1607 \mathrm{bp}$ of $18 \mathrm{~S}$ rDNA sequence data with that of other myxozoans in GenBank produced no match; the highest similarity is with Myxobolus impressus (AF507970; 93.8\% over 1448 bp, gapped), the putative actinosporean stage of which is unknown.

Differential diagnosis. The morphometrics of Triactinomyxon type 1 nov. are consistent with those of the triactinomyxon stage of Myobolus macrocapsularis (32 germ cells), although in the latter the processes do not taper as severely, distally. Comparison of their $18 \mathrm{~S}$ rDNA sequences, however, revealed that the 2 triactinomyxons are only 90.5\% similar over 1434 bp, which indicates that they are different types. Rácz \& Timm (2002) recognised also that their Triactinomyxon type 2 showed a great similarity to the triactinomyxon stage of $M$. macrocapsularis, but noted that the sporoplasm of newly released spores contained 16 germ cells which later doubled to 32. Neither we nor Székely et al. (2002a) observed such an increase.

\section{Triactinomyxon type 2 nov. $\mathrm{n}=15$ (Fig. 3)}

Reference material. Spore possesses spore body, style and 3 caudal processes. Spore body length with sporoplasm, ovate, contains 30 or 32 germ cells, and 3 prominent, pyriform, polar capsules positioned apically; 3 valve cells, fused, surround polar capsules and sporoplasm and beneath this spore body complex form 


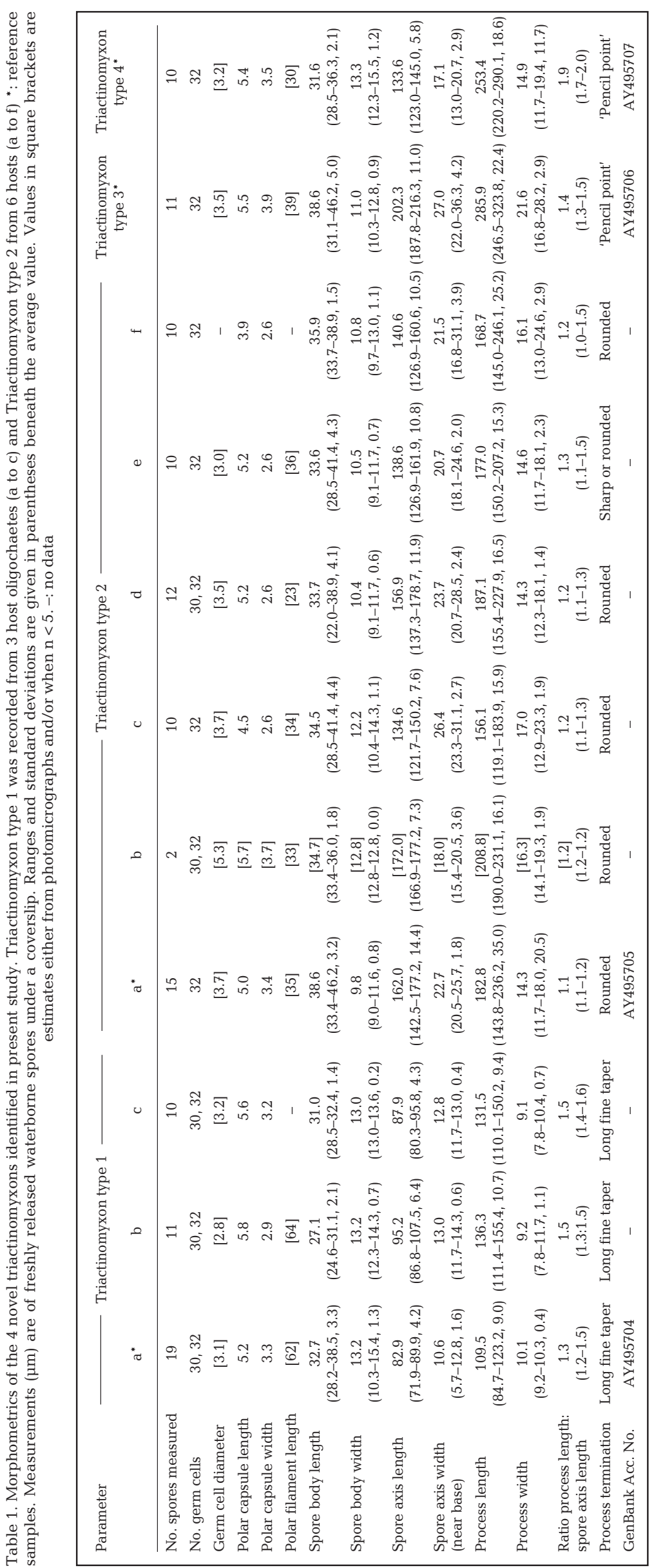

an elongate style, which widens to base where valve cells diverge to each form an elongate caudal process that curves upwards slightly and tapers to a sharp or rounded point. Relative length of processes variable (sometimes 2 longer, 1 shorter and vice versa); valve cell nuclei observed in variable locations along processes.

Host of reference material. Tubifex tubifex.

Site in host. Intercellular in intestinal epithelium.

Source of material. Pet shop (Sample D 4), Munich (8 August 2001).

Specimens deposited. Giemsa and DiffQuik slides of air-dried spores deposited in the Queensland Museum, Brisbane, Australia, Accession Nos. G464763 and G464764 (however, specimens are not given type status in the sense of the International Code of Zoological Nomenclature).

Remarks. Sporoplasm readily mobile in spore axis. We isolated 6 oligochaetes infected with this actinosporean type from the sample (Tri 2a to f). The morphometrics of each of these are detailed in Table 1. The difference in length of the shortest and longest caudal processes of a single spore is greatest for Tri 2a (9 to $63 \mu \mathrm{m})$. Spores were observed with either 30 or 32 germ cells.

Molecular data. The 18S rDNA of 5 of these was partially sequenced to yield 1814 bp (Tri 2a) (GenBank Accession No. AY495705), 1779 bp (Tri 2c), 1776 (Tri 2d), $341 \mathrm{bp}$ (Tri 2e) and $341 \mathrm{bp}$ (Tri 2f). Over a $1771 \mathrm{bp}$ alignment there are 2 base differences between Tri 2a and 2c, 4 base differences between Tri $2 \mathrm{a}$ and $2 \mathrm{~d}$, and 1 base difference between Tri 2c and 2d. There are no base differences between any samples in the $341 \mathrm{bp}$ region represented by Tri $2 \mathrm{e}$ and $2 \mathrm{f}$. A sequence identity matrix of the 5 triactinomyxons described herein showed that Triactinomyxon type 2 is most similar to Triactinomyxon type 3 (93.2\%) over 1432 bp. A BLAST search revealed no match for this actinosporean; over $1578 \mathrm{bp}$ it is most similar to Myxobolus impressus (92.6\%, gapped).

Differential diagnosis. Morphometrical, morphological and molecular data distinguish this type from the 4 other triactino- 


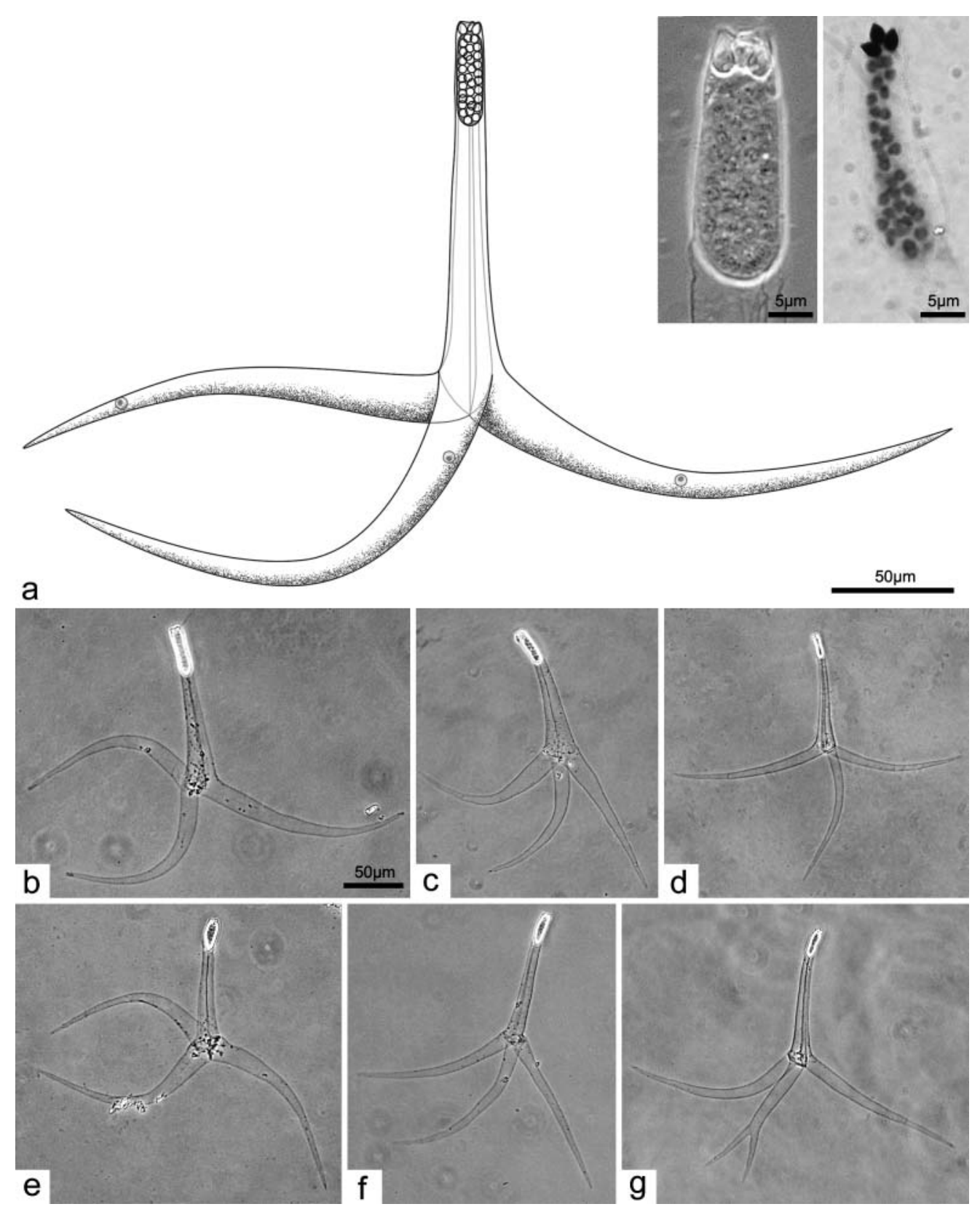

Fig. 3. Triactinomyxon type 2 nov. (a) Line drawing of mature spore; inset: spore body, left = fresh, unstained, right = Giemsastained highlighting germ cells and polar capsules. (b-g) Range of morphological exemplars released from different host oligochaetes, all at about same scale. Note various shapes and positions of caudal processes and slight differences in shape of sporoplasm. 18S rDNA indicated that all were the same species; fresh, unstained, under coverslip. (b) Tri 2a; (c) Tri 2c; (d) Tri 2d;

(e) Tri 2e; (f) Tri 2f; (g) Tri 2 mutant

myxons isolated in this study. Comparison with triactinomyxons in the literature with 30 or 32 germ cells revealed a resemblance to 3 types: the triactinospore of Myxobolus portucalensis, Triactinomyxon type 1 of Székely et al. (2002b) and Triactinomyxon type 4 of Oumouna et al. (2003). All dimensions of M. portucalensis are consistent with Triactinomyxon type 2 nov., although spore axis length of the former is at the low end of our range (142 to 143.5 vs. 142.5 to 177.2 ).
However, comparison of the molecular data of Oumana et al. (2003) showed that the two are only $73 \%$ similar over 1579 to 1656 bp. Dimensions of Székely type 1 also overlap with our type 2, except that the width of the caudal processes of our type 2 is greater. (Spore body parameters were not provided by Oumana et al. (2003); we compared our spore body with the sum of their sporoplasm and polar capsules to gain an estimate). The 2 types appear to differ in 


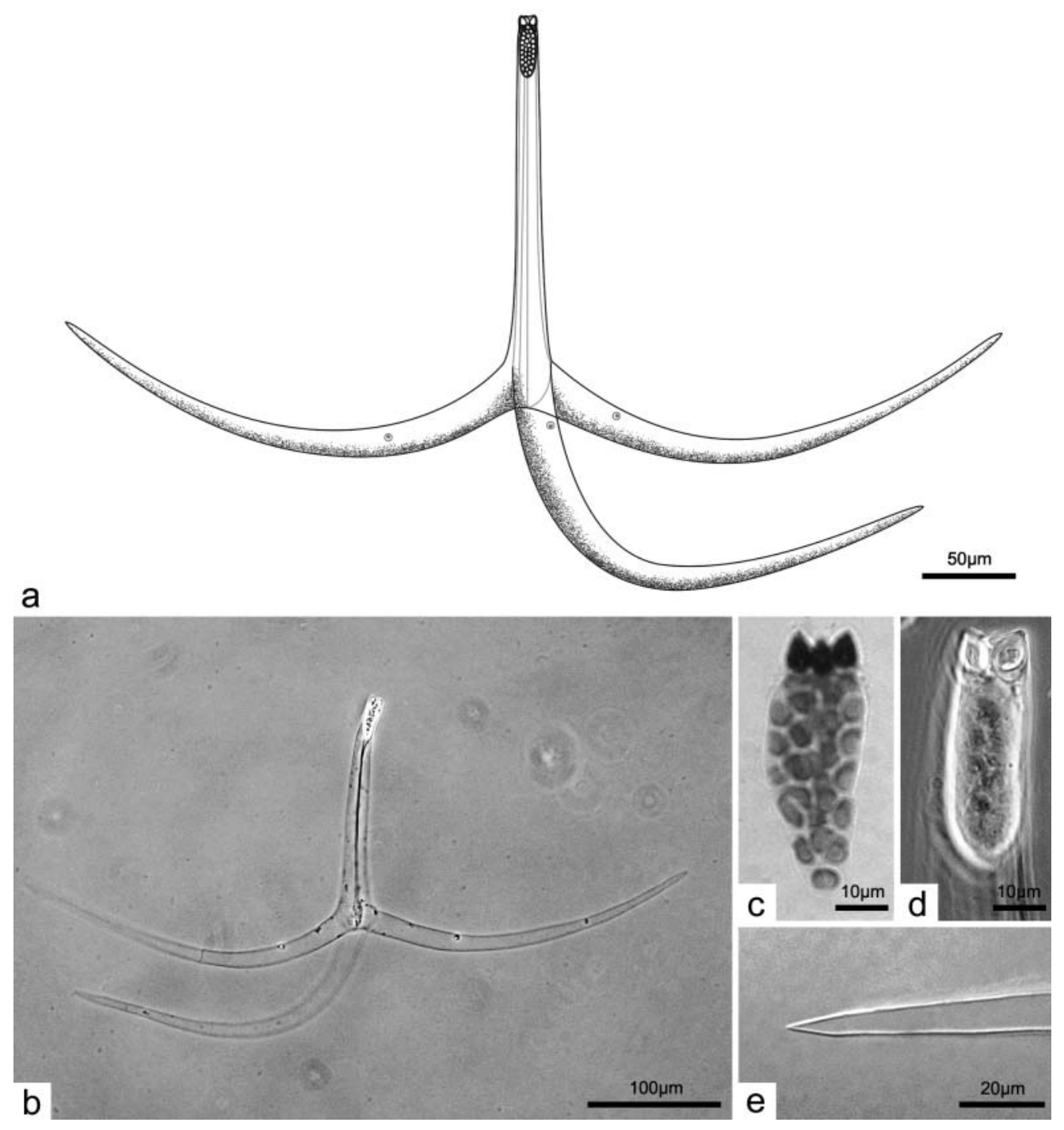

Fig. 4. Triactinomyxon type 3 nov. (a) Line drawing of mature spore. (b) Mature waterborne spore, fresh, unstained, under coverslip. (c) Giemsa-stained spore body highlighting germ cells in sporoplasm and polar capsules at spore apex. (d) Higher magnification of spore body; fresh, unstained, under coverslip. (e) Higher magnification of caudal process termination showing distinctive 'pencil point'; tapering

morphology of the spore body, host type and locality. The 3 characters reported for the Oumouna type 4 fit within those reported here for our type 2, but there is only a limited data set available for comparison. However, without molecular data for Székely type 1 and Oumouna type 4, it is not possible to be definitive about their relationship to our Tri type 2, although on balance we are comfortable calling Tri type 2 novel.

\section{Triactinomyxon type 3 nov. $n=11$ (Fig. 4)}

Reference material. Spore possesses spore body, style and 3 caudal processes. Spore body with sporoplasm, contains 32 germ cells and 3 prominent, pyriform, polar capsules, positioned apically; 3 valve cells, fused, surround polar capsules and sporoplasm and beneath this spore body complex form an elongate style, which widens to base where valve cells diverge to each form an elongate caudal process that curves slightly upwards and tapers to a 'pencil point'. Processes approximately equal in length; valve cell nuclei near style base.

Host of reference material. Tubifex tubifex.

Site in host. Intercellular in intestinal epithelium.

Source of material. Pet shop (Sample D4), Munich (8 August 2001).

Specimens deposited. A Diff-Quik slide of air-dried spores deposited in the Queensland Museum, Brisbane, Australia, Accession No. G464765 (however, specimens 


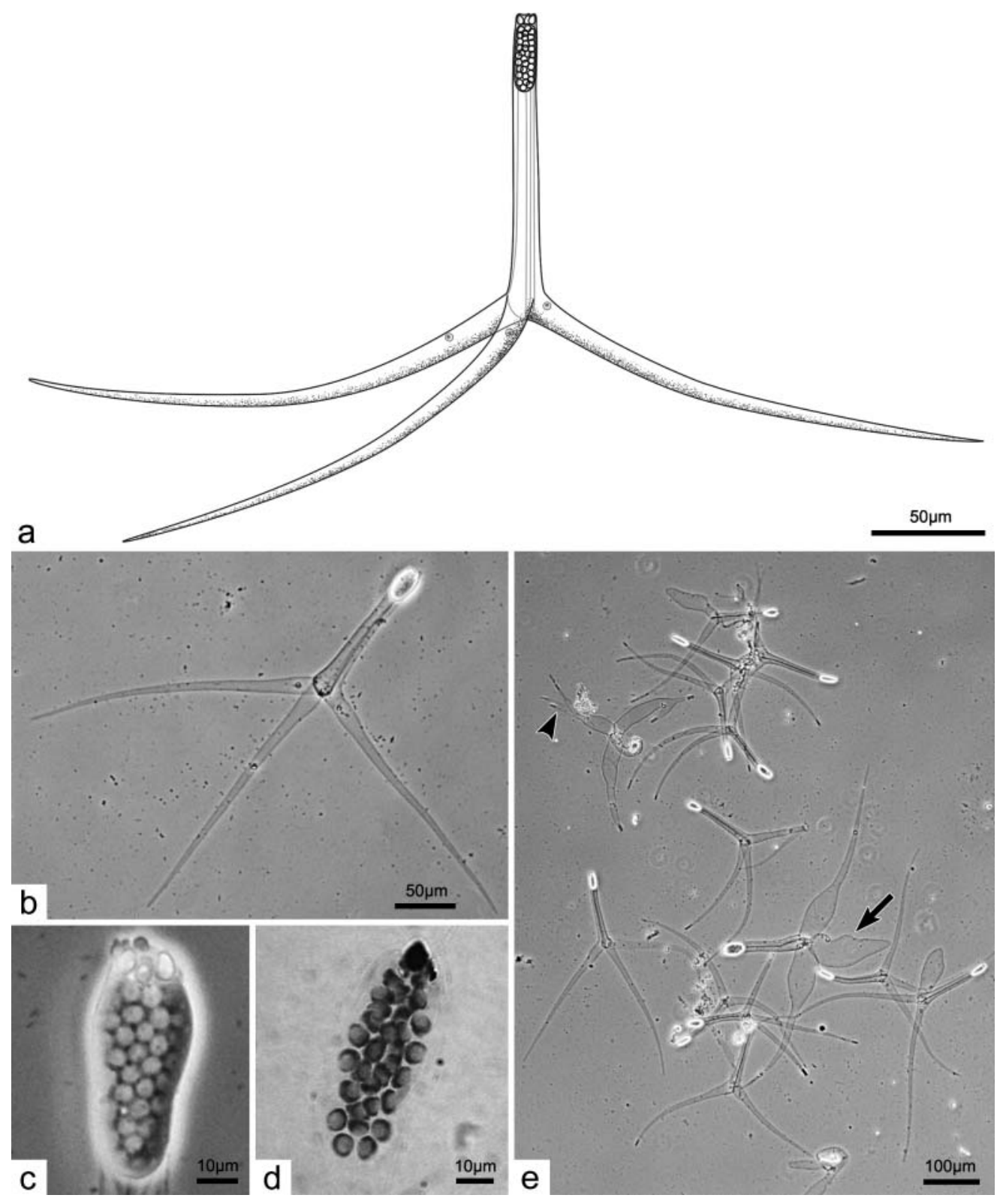

Fig. 5. Triactinomyxon type 4 nov. (a) Line drawing of mature spore. (b) Mature waterborne spore; fresh, unstained, under coverslip. (c) Higher magnification of spore body, which is somewhat compressed under coverslip; fresh, unstained. (d) Giemsa-stained spore body highlighting germ cells and 1 of polar capsules. (e) Photomicrograph illustrating range of spore morphotypes released from 1 host oligochaete. Note aberrant spores among perfectly formed ones; arrow indicates excessively swollen caudal process, and arrowhead a furcated caudal process

are not given type status in the sense of the International Code of Zoological Nomenclature).

Remarks. This parasite was released by 2 oligochaetes from the sample. The difference in length of the 3 caudal processes ranged from 0 to $31 \mu \mathrm{m}$; no pattern of variation was discerned. Spores were only observed with 32 germ cells. Caudal processes tapered gradually until the last 10 to $15 \mu \mathrm{m}$, where they taper more severely to a sharp point, resembling the sharpened end of a pencil.
Molecular data. We sequenced $1629 \mathrm{bp}$ of $18 \mathrm{~S}$ rDNA (GenBank Accession No. AY495706). A sequence identity matrix of the 5 triactinomyxons described herein showed that Triactinomyxon type 3 was most similar to Triactinomyxon type 2 (93.2\%) over $1432 \mathrm{bp}$. A BLAST search revealed no match; the closest identity is with Myxobolus impressus (92.5\% over 1579 bp, gapped) and M. muelleri (92.6\% over $1371 \mathrm{bp}$ ).

Differential diagnosis. Morphometrically, morphologically and molecularly this type can be distinguished 
from the other triactinomyxons isolated in this study. Of published records, spore morphometrics overlap with those of Triactinomyxon $\mathrm{C}$ of Xiao \& Desser (1998a), but Triactinomyxon type 3 has only half the number of germ cells, and pairwise alignment of the 2 $18 \mathrm{~S}$ rDNA sequences showed only $71 \%$ similarity. The averages provided for Triactinomyxon type 4 of El-Mansy et al. (1998c) fall within our ranges, but neither data ranges nor a germ cell count are available for their Tri; we cannot therefore be definitive in our differential diagnosis, although on balance we are comfortable calling Tri type 3 novel.

\section{Triactinomyxon type 4 nov. $n=10$ (Fig. 5)}

Reference material. Spore possesses spore body, style and 3 caudal processes. Spore body with sporoplasm, pill-shaped, contains 32 germ cells and 3 prominent, pyriform, polar capsules, positioned apically which protrude from spore body; 3 valve cells, fused, surround polar capsules and sporoplasm and beneath this spore body complex form an elongate style, which widens to base where valve cells diverge to each form an elongate caudal process, that curves slightly upwards or downwards and tapers to terminate in a 'pencil point'. Processes approximately equal in length; valve cell nuclei near style base.

Host of reference material. Died before processing. Site in host. Not determined.

Source of material. Pet shop (Sample AC2), Munich (28 February 2002).

Specimens deposited. A Diff-Quik slide of air-dried spores deposited in the Queensland Museum, Brisbane, Australia, Accession No. G464766 (however, specimens are not given type status in the sense of the International Code of Zoological Nomenclature).

Remarks. We identified 1 oligochaete from 1 tubifex sample as producing the spores. These were observed within $24 \mathrm{~h}$ of release from host; within $48 \mathrm{~h}$ in the latter group there were many malformed spores (Fig. 5). Spores were only observed with 32 germ cells. Caudal processes tapere gradually until the last 10 to $15 \mu \mathrm{m}$ where they taper more severely to a sharp point, resembling the sharpened end of a pencil.

Molecular data. 1456 bp were sequenced (GenBank Accession No. AY495707). A sequence identity matrix of the 5 triactinomyxons described herein was constructed in BioEdit (Hall 1999) and showed that Triactinomyxon type 4 is most similar to Triactinomyxon type 1 (98.8\%; see 'Discussion', Molecular analyses') over $1432 \mathrm{bp}$. A BLAST search revealed no match; the closest identity is to Myxoblus impressus (93.8\% over 1427 bp, gapped).
Differential diagnosis. Comparison with published forms showed that phenotypically type 4 is very similar to the triactinomyxon stage of Myxobolus bramae. Pairwise comparison of their 18S rDNA sequences, however, showed definitively that the 2 are different types, with only $75 \%$ similarity.

\section{Triactinomyxon of Hallett et al. (2004) (type 5) (Fig. 6)}

This fifth type of triactinomyxon was released by 39 Tubifex tubifex isolated from 2 worm samples obtained from the same pet shop (Samples D2 and D4) on the 22 June and 8 August 2001. A full description appears in Hallett et al. (2004). Diff-Quik and Giemsa slides of airdried spores deposited in the Queensland Museum, Brisbane, Australia, Accession Nos. G464767 and G464768. Spores have 8 germ cells and 2 longer and 1 shorter caudal process with distinctly blunt ends (Fig. 6). Spores exhibit considerable variation in their morphometrics: the 2 longer caudal processes range from 147.5 to $272.0 \mu \mathrm{m}$ in length, the shorter process from 70.0 to $176.0 \mu \mathrm{m}$, the spore axis from 121.5 to $178.5 \mu \mathrm{m}$. Across 110 spores from 11 hosts, the ranges of dimensions of the smallest and largest exemplars were mutually exclusive. $1554 \mathrm{bp}$ of 18S rDNA was sequenced and is available in GenBank, Accession No. AY162270. A sequence identity matrix of the 5 triactinomyxons reported herein showed that the triactinomyxon of Hallett et al. 2004 is most similar to Triactinomyxon type $4(78.6 \%)$ over 1432 bp. A FASTA search indicated that this triactinomyxon is most similar to Myxobolus pseudodispar ex bream, with $96.9 \%$ similarity. Multiple M. pseudodispar sequences can be found in GenBank. Alignment of our triactinomyxon sequence with 4 of these (from 4 different hosts) revealed that our triactinomyxon shares 95.4 to $96.7 \%$ of its bases with the M. pseudodispar isolates, whilst the isolates are 95.8 to $98.8 \%$ similar (Hallett et al. 2004).

\section{Riboprint analysis}

This method indicated a high degree of genetic relatedness over the template region between Triactinomyxon types 2 and 3, since neither of the restriction endonucleases (Dde1 and Hha1) distinguished between them (Fig. 7). Comparison of their 18S rDNA sequences revealed 92\% similarity over 1626 bases (127 base differences). Both enzymes, however, were able to distinguish Triactinomyxon type 1 and the triactinomyxon of Hallett et al. (2004). Note that Triactinomyxon type 4 had not been found at the time the digest was performed. 


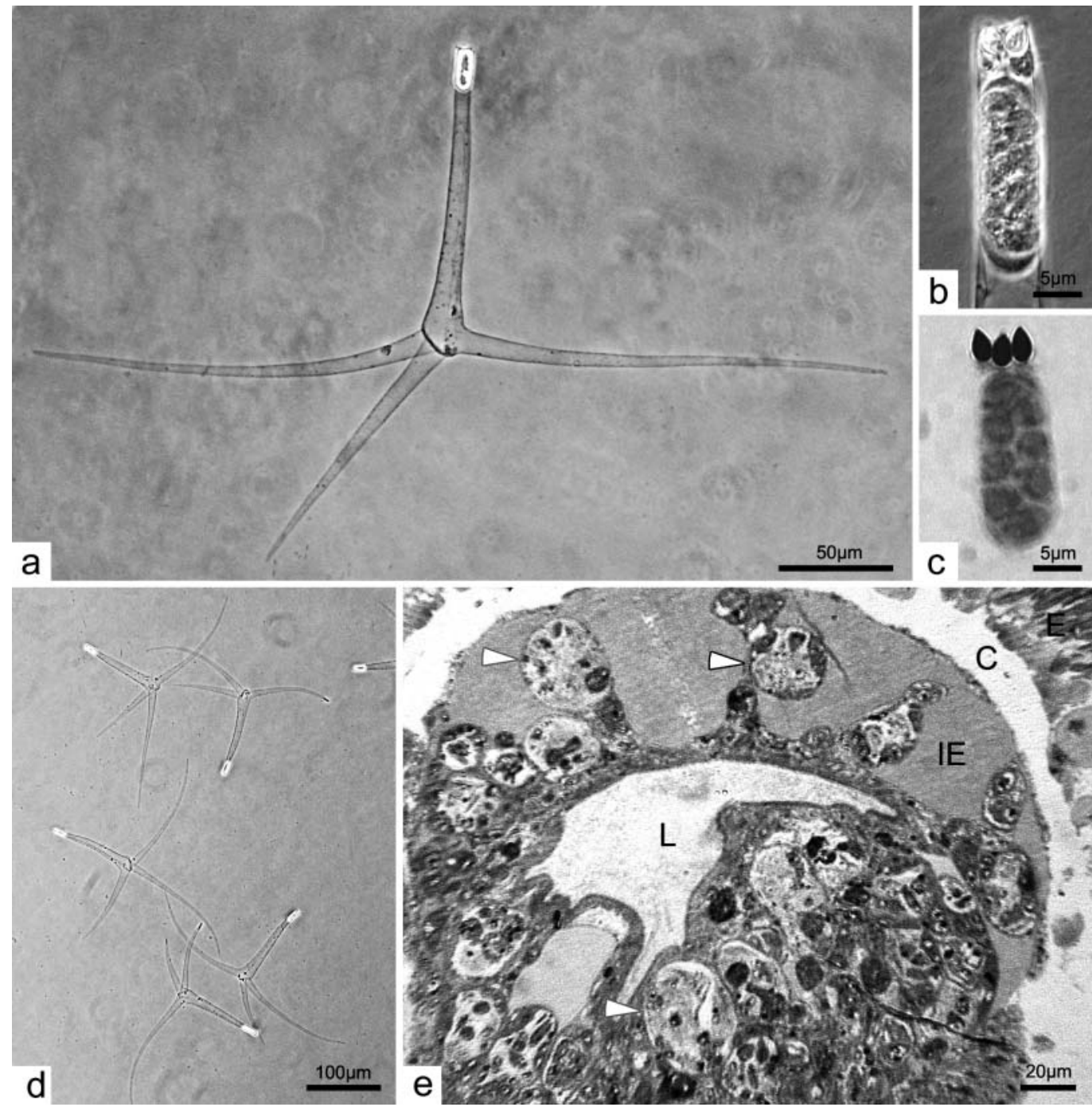

Fig. 6. Triactinomyxon of Hallett et al. (2004). (a) Mature waterborne spore. (b) Higher magnification of spore body showing polar capsules with associated capsulogenic cells; fresh, unstained; (c) Giemsa-stained spore body highlighting germ cells and polar capsules. (d) Group of fresh waterborne spores. (e) Semithin section of host oligochaete (E: epidermis; C: coelom; IE: intestinal epithelium; L: intestinal lumen; arrowheads indicate pansporocycts, intercellular in IE)

\section{DISCUSSION}

Live oligochaetes commonly sold as 'tubifex' worms may comprise a mixture of species including the tubificids Tubifex tubifex, Limnodrilus hoffmeisteri, and Rhyacodrilus coccineus, the naidid Dero digitata, and the lumbriculid Lumbriculus variegatus (Beauchamp et al. 2001). From several 'tubifex' samples purchased in Munich, we identified 2 of these species: T. tubifex and L. hoffmeisteri, as well as L. udekemianus. All 6 species have been documented as hosts for actinosporeans (Marquès 1984, Xiao \& Desser 1998a, Kent et al. 2001) and 5 have been demonstrated to alternate with a fish as host for a myxozoan (see Kent et al. 2001).

\section{Terminology}

Members of the former class Actinosporea are now generally recognised as probable alternate stages of myxosporean parasites and, as such, actinosporean genera have been replaced by collective groups and species by 'species inquirendae' and types (Kent et al. 1994). Consequently, we have used the term 'reference' in the species descriptions (i.e. 'reference material') in lieu of the term 'type specimen' both to avoid confusion with type members of each collective group and to ensure accurate species reporting. Although we believe the actinosporeans described herein are previously undocumented, without molecular data (for both stages) or in vivo life cycle information, we cannot 

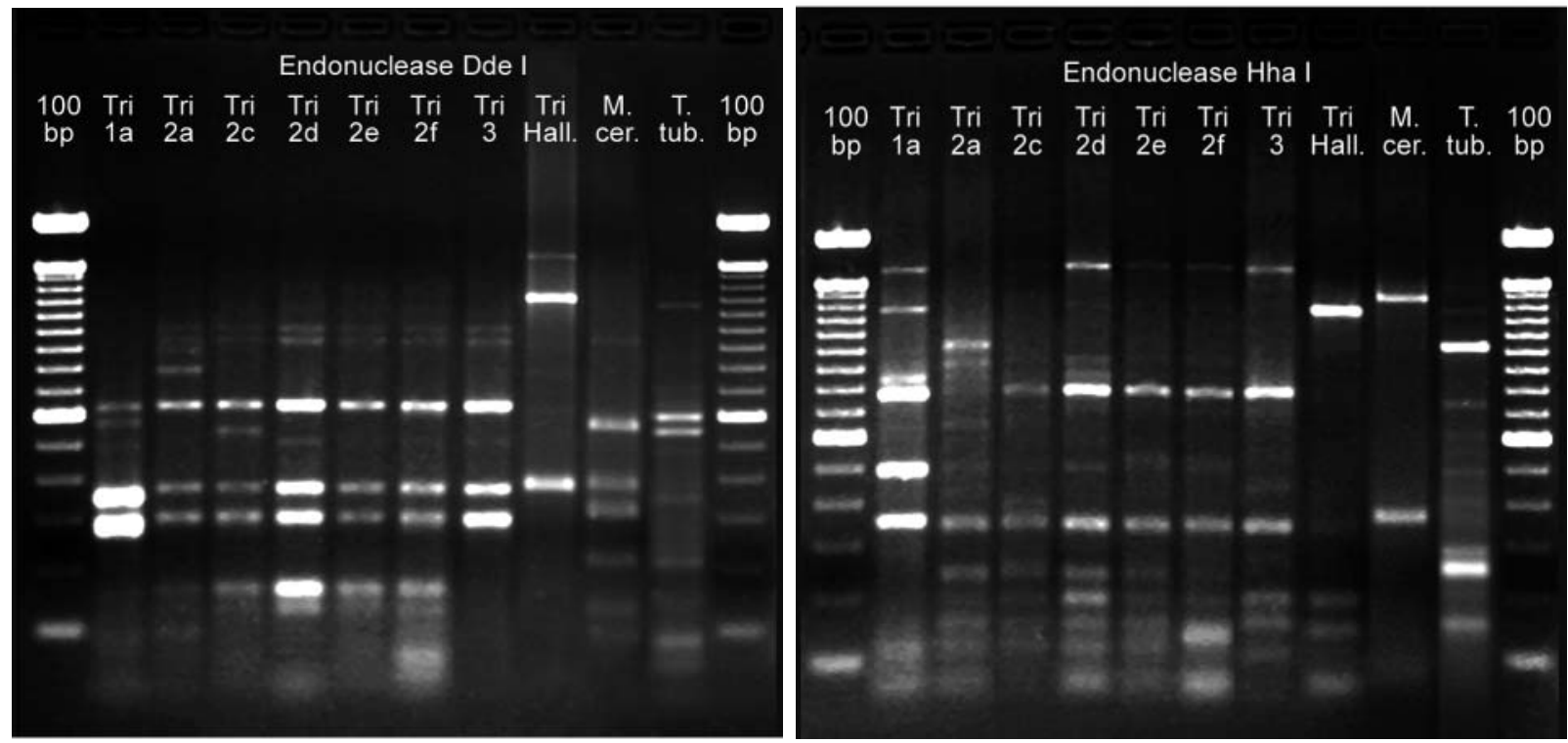

Fig. 7. Riboprint patterns of triactinomyxon 18S rDNA produced by 2 restriction endonucleases Dde1 (top gel) and Hha1 (bottom gel): 100 bp: ladder; Tri Hall.: triactinomyxon of Hallett et al. (2004); M. cer.: Myxobolus cerebralis; T. tub.: Tubifex tubifex (uninfected host material)

know whether their putative myxosporean counterparts are already known and hence cannot designate our spores as 'type' specimens with certainty.

\section{Descriptions}

Triactinomyxon was the most speciose and prevalent actinosporean group infecting our oligochaete samples, with 50 worms parasitised. We used morphological and morphometrical data as an initial indicator of the number of types present. Molecular data obtained from 18S rDNA sequences then enabled designation of discrete identities with greater confidence. The 50 triactinomyxon infections broke down into 5 spore types, represented by 1 to 39 infections.

Triactinomyxon spores are readily identifiable by their anchor-shape when fully inflated following release from the oligochaete host. They are fragile and susceptible to incomplete inflation of their caudal processes, and spore components degrade readily (especially the sporoplasm). It can therefore be difficult to find 'perfect' spores to measure (i.e. all 3 processes everted, sporoplasm tightly under/abutting polar capsules, polar capsules unfired). To define spore types, one therefore needs a set of the most stable and reproducible characters. Xiao \& Desser (1998a) considered dimensions of the spore axis (the distance from the tip of the polar capsules to the base of the spore, which comprises the spore body and 'style'), the caudal processes and the polar capsules to be important and reliable taxonomic characters for identification of tri- actinomyxons. They also commented that the stylethe region of the spore axis between the base of the spore and the start of the spore body-is an unreliable character given the mobile nature of the sporoplasm. Özer et al. (2002) added that although the style and caudal processes are significant, intraspecific size variation creates problems for species comparison based on these characters. We agree, and support the use of spore axis over style, and also note that the spore axis length is a less variable metric not as prone to effects of curvature as the caudal processes, and varies little from compression under a coverslip.

Additionally, Xiao \& Desser (1998a) considered the number of germ cells and the size of the sporoplasmic mass in fresh spores to be valuable characters. Özer et al. (2002) added that the number of germ cells is of particular importance in species identification of triactinomyxons. However, Xiao \& Desser (1998a) noted an increase in the number of germ cells and size of the sporoplasmic mass in several triactinomyxons after release from the host. In contrast, El-Matbouli \& Hoffmann (1989) recorded a halving in the number of germ cells of the triactinomyxon of Myxobolus cotti after it was waterborne. These 2 records of post-release variation highlight the need for explicit observation of germ cell number in both freshly released and slightly older spores so as not to jeopardise the usefulness of this character. With this in mind, we examined spores at various time intervals up to $1 \mathrm{wk}$ post-host-release and did not observe a change in any sporoplasms of the triactinomyxons under study. We did however observe spores of the same type with 2 distinct germ cell numbers (both for Tri 1 and 2). 
Xiao \& Desser (1998a) also observed that the sporoplasm of triactinomyxon spores was released posteriorly. Although we observed that the sporoplasm in older spores often moved and spread out down the spore axis, we never witnessed the exit of the sporoplasm through the base of the spore, nor did we ever observe separation of the valve-cell sutures at the base. Rather, we always observed the sporoplasm to leave the spore anteriorly, associated with firing of the polar capsules: the valve cells partially separate along their sutures and the sporoplasmic mass is released (see Fig. 2e).

\section{Molecular analyses}

To determine the number of spore types present prior to sequencing, we used a riboprint analysis. Riboprinting involves the use of 1 or more restriction endonucleases to cleave a known segment of a gene to generate multiple fragments, which produce a unique band pattern when electrophoresed on a gel (Clark 1997). Myxozoans are well-suited for this technique since their $18 \mathrm{~S}$ rDNA sequences are remarkably variable between even closely related taxa (Kent et al. 2001). Samples with different banding patterns should be readily identifiable as different species. However, one must exercise caution when interpreting riboprints, as samples that share a similar pattern may not be the same species if their genomic differences lie in an area not targeted by the selected enzyme. This was the case for 2 of our triactinomyxons as well as for 2 studied by Xiao \& Desser (2000); these authors used 9 endonucleases, we used only 2. Comparison of the sequences of the riboprinted region for each pair of these ambiguous triactinomyxons revealed 92 and $95 \%$ sequence similarity, respectively.

In previous studies we have advocated the usefulness of a short section of 18S rDNA sequence to discriminate between types of actinosporeans; the $300+$ bases near the $5^{\prime}$ end typically contain a mix of conserved and variable segments (Hallett et al. 2002, 2003). It should be noted, however, that this region was identical for Triactinomyxon types 1 and 4 in the present study (but these spore types differed in 13 to 16 base positions over the extended $1456 \mathrm{bp}$ of $18 \mathrm{~S}$ rDNA, and were readily distinguished from each other based on phenotypic comparisons). A sequence identity matrix of the 5 triactinomyxons in this study indicated similarities ranging from 78.1 to $98.8 \%$ over an aligned $1432 \mathrm{bp}$.

We have found that the additional information provided by molecular data has been pivotal in the accurate and confident classification of the actinosporeans we isolated. Frequently, spores released by one oligo- chaete were similar but not identical to spores of the same type released by another. For example, although the 6 Triactinomyxon type 2 groups shared the same basic morphology and number of germ cells, a range in measurements was recorded (see Table 1). We were initially uncertain whether these morphometrical differences were meaningful. However, from 18S rDNA sequence data we concluded that the spores were the same species since the maximum number of base differences between any 2 samples (over a 1771 bp alignment) was $4(0.2 \%$ divergence $)$. This divergence is well within the value $(<2 \%)$ determined for samespecies isolates of several myxozoans (myxosporean stage) from different hosts or geographic locations (see summary in Hallett et al. 2004).

Were it not for molecular data, Triactinomyxon type 1 nov. might have been misidentified, since its dimensions, number of germ cells and host species were consistent with those of the actinosporean stage of Myxobolus macrocapsularis, the only apparently minor disparity being that the processes of the latter do not taper as severely distally. Comparison of their $18 \mathrm{~S}$ rDNA sequences revealed that the 2 triactinomyxons were only $90.5 \%$ similar over $1434 \mathrm{bp}$, and hence we are confident that they are different types. Similarly, the final determination of Tri type 4 was settled by molecular data-otherwise this spore was almost indistinguishable from the triactinosporean stage of M. bramae.

\section{Origin of worms}

Unfortunately we could not obtain exact source information for the oligochaetes; understandably, shop owners were concerned about potential commercial repercussions of disclosing such details. Of the 3 shops, 1 reported stocks originating from Romania and Hungary. Myxozoans from Hungary have been relatively well documented, unlike those from Romania. Some 34 types of actinosporeans are known, 9 of which are triactinomyxons (El-Mansy et al. 1998b,c). None of the types we isolated appear to be any of these, with the possible exception of our Triactinomyxon type 3, which cannot be definitively distinguished from Triactinomyxon type 4 of El-Mansy et al. (1998c) (see differential diagnosis for Triactinomyxon type 3 nov. in 'Results'), who recorded 3 triactinomyxon types from from Tubifex tubifex, 2 from Limnodrilus hoffmeisteri, 3 from water associated with these 2 species and 1 from water associated with a range of species; our 5 types infected only $T$. tubifex. El-Mansy et al. $(1998 b, c)$ reported about 10 myxosporeans from a local lake and about 28 species from a fish farm. It is not clear if any are alternating stages of the 1 myxozoan 
species since molecular data for both stages has not been generated and just 3 life cycles are known (although this number is considerable compared with other habitats); a further 3 triactinomyxons (Myxobolus drjagini, $M$. hungaricus, and $M$. portucalensis) have been described in these life cycle experiments (ElMansy \& Molnár 1997a,b, El-Mansy et al. 1998a).

So far, all triactinomyxons whose life cycles have been determined develop into a myxobolus myxospore (Kent et al. 2001, Székely et al. 2002a). However, the converse does not always apply: of the 13 known Myxobolus life cycles, $M$. cultus and $M$. dispar alternate with a raabeia actinospore; $M$. pavlovskii alternates with a hexactinomyxon (Kent et al. 2001). In 11 of these cases, Tubifex tubifex or a mixture of worms containing T. tubifex were identified as the invertebrate host. Although we identified 3 different tubificid species in the 'tubifex' mix, only $T$. tubifex were infected with triactinomyxon parasites.

\section{Parasite and host dispersal}

Diseases caused by bacteria, viruses and parasites are all too often conveyed along with introduced aquatic species (see Hoffman \& Schubert 1984, Shotts \& Gratzek 1984 for reviews).The potential for accidental introduction of myxozoan parasites facilitated by international transport of their invertebrate oligochaete hosts was first assessed by Lowers \& Bartholomew (2003), who detected 7 types of triactinomyxons in 3 separate shipments of 'tubifex' worms imported to the USA from eastern Europe as live food for aquarium fishes. Given that Tubifex tubifex is an ubiquitous complex of species found in sediments from Europe to America and Australia, we feel there is legitimate concern for co-transportation and establishment of its parasite fauna in new areas with transport of live worms.

If myxozoan parasites are introduced into an aquarium or pond from infected live oligochaetes, there are several potential routes via which they could conceivably be released into the environment at large. The parasite in its actinosporean stage may be directly released with infected water: even though actinospores are fragile they can be viable for some time; Myxobolus cerebralis triactinomyxon for example has been shown to remain infective for $>15 \mathrm{~d}$ at water temperatures up to $15^{\circ} \mathrm{C}$ (El-Matbouli et al. 1999). Infected invertebrate hosts may be released directly: when live oligochaetes are added to a tank as food, rarely are all worms eaten before burrowing into the substrate, where they often survive and multiply. We have observed infected oligochaetes to continue to produce spores for over 12 mo. Overflow or exchange of tank/pond water can carry waterborne spores. If the tank/pond substrate is discarded, infected oligochaetes could easily be included.

Escape of a myxozoan parasite may not require direct release of the actinosporean stage and/or its oligochaete host from the aquarium. If susceptible fishes have become infected and are then released (it is not unusual for unwanted aquarium or pond fish to be 'freed' into the wild), the myxospores they carry could readily infect the available wild oligochaete population and perpetuate the parasite life cycle.

The risk of dissemination of parasites with live oligochaetes used as food for aquarium fishes is by no means a novel concept, indeed tubifex worms have been fed to aquarium fish for over $100 \mathrm{yr}$ and it is known by fish food suppliers that these can introduce bacteria and disease into tanks. Many suppliers now provide gamma-irradiated and freeze dried worms: not only is the host killed, but freezing or drying triactinomyxons for $1 \mathrm{~h}$ has been demonstrated to render them unviable (Wagner et al. 2003). Issues of infections spread via live worms can also be sidestepped altogether as other live foods are commonly available to aquarists including insect larvae, which we have observed to be a suitable substitute for the tastes of discerning fishes.

Acknowledgements. We are most appreciative of the support of the Alexander von Humboldt Foundation (Germany), which awarded a Research Fellowship (Munich) and a Europe Fellowship (Sweden) to S.L.H.

\section{LITERATURE CITED}

Altschul SF, Madden TL, Schäffer AA, Zhang J, Zhang Z, Miller W, Lipman DJ (1997) Gapped BLAST and PSIBLAST: a new generation of protein database search programs. Nucleic Acids Res 25:3389-3402

Andree KB, MacConnell E, Hedrick RP (1998) A nested polymerase chain reaction for the detection of genomic DNA of Myxobolus cerebralis in rainbow trout Oncorhynchus mykiss. Dis Aquat Org 34:145-154

Beauchamp KA, Kathman RD, McDowell TS, Hedrick RP (2001) Molecular phylogeny of tubificid oligochaetes with special emphasis on Tubifex tubifex (Tubificidae). Mol Phylogenet Evol 19:216-224

Clark CG (1997) Riboprinting: a tool for the study of genetic diversity in microorganisms. J Eukaryot Microbiol 44: $277-283$

El-Mansy A (2001) First record of actinosporean stages of fish myxosporean parasites in Egypt. J Egypt Soc Parasitol 31:449-465

El-Mansy A, Molnár K (1997a) Extrapiscine development of Myxobolus drjagini Akhmerov, 1954 (Myxosporea: Myxobolidae) in oligochaete alternative hosts. Acta Vet Hung 45:427-438

El-Mansy A, Molnár K (1997b) Development of Myxobolus hungaricus (Myxosporea: Myxobolidae) in oligochaete alternate hosts. Dis Aquat Org 31:227-232 
El-Mansy A, Molnár K, Székely C (1998a) Development of Myxobolus portucalensis Saraiva \& Molnár, 1990 (Myxosporea: Myxobolidae) in the oligochaete Tubifex tubifex (Müller). Syst Parasitol 41:95-103

El-Mansy A, Székely C, Molnár K (1998b) Studies on the occurrence of actinosporean stages of fish myxosporeans in a fish farm of Hungary, with the description of triactinomyxon, raabeia, aurantiactinomyxon and neoactinomyxon types. Acta Vet Hung 46:259-284

El-Mansy A, Székely C, Molnár K (1998c) Studies on the occurrence of actinosporean stages of myxosporeans in Lake Balaton, Hungary, with the description of triactinomyxon, raabeia, and aurantiactinomyxon types. Acta Vet Hung 46:437-450

El-Matbouli M, Hoffmann RW (1989) Experimental transmission of 2 Myxobolus spp. developing bisporogeny via tubificid worms. Parasitol Res 75:461-464

El-Matbouli M, Hoffmann RW (1993) Myxobolus carassii Klokaceva, 1914 also requires an aquatic oligochaete, Tubifex tubifex as an intermediate host in its life cycle. Bull Eur Assoc Fish Pathol 13:189-192

El-Matbouli M, Hoffmann RW (1998) Light and electron microscopic studies on the chronological development of Myxobolus cerebralis to the actinosporean stage in Tubifex tubifex. Int J Parasitol 28:195-217

El-Matbouli M, Hoffmann RW, Schöl H, McDowell TS, Hedrick RP (1999) Whirling disease: host specificity and interaction between the actinosporean stage of Myxobolus cerebralis and rainbow trout Oncorhynchus mykiss. Dis Aquat Org 35:1-12

Eszterbauer E, Székely C, Molnár K, Baska F (2000) Development of Myxobolus bramae (Myxosporea: Myxobolidae) in an oligochaete alternate host, Tubifex tubifex. J Fish Dis 23:19-25

Gilbert MA, Granath WO Jr (2003) Whirling disease of salmonid fish: life cycle, biology, and disease. J Parasitol 89:658-667

Hall TA (1999) BioEdit: a user-friendly biological sequence alignment editor and analysis program for Windows 95/98/NT. Nucleic Acids Symp Ser 41:95-98

Hallett SL, Diamant A (2001) Ultrastructure and small-subunit ribosomal DNA sequence of Henneguya lesteri n.sp. (Myxosporea), a parasite of sand whiting Sillago analis (Sillaginidae) from the coast of Queensland, Australia. Dis Aquat Org 46:197-212

Hallett SL, Erséus C, O'Donoghue PJ, Lester RJG (2001) Parasite fauna of Australian marine oligochaetes. Mem Queensl Mus 46:555-576

Hallett SL, Atkinson SD, El-Matbouli M (2002) Molecular characterisation of 2 aurantiactinomyxon (Myxozoa) phenotypes reveals one genotype. J Fish Dis 25:627-631

Hallett SL, Atkinson SD, Schöl H, El-Matbouli M (2003) Characterisation of 2 novel types of hexactinomyxon spores (Myxozoa) with subsidiary protrusions on their caudal processes using scanning electron microscopy and $18 \mathrm{~S}$ rDNA sequence data. Dis Aquat Org 55:45-57

Hallett SL, Atkinson SD, Erséus C, El-Matbouli M (2004) Molecular methods clarify morphometric variation in triactinomyxon (Myxozoa) spores released from different oligochaete hosts. Syst Parasitol 57:1-14

Hillis DM, Dixon MT (1991) Ribosomal DNA: molecular evolution and phylogenetic inference. Q Rev Biol 66:411-453

Hoffman GL, Schubert G (1984) Some parasites of exotic fishes. In: Courtenay WR Jr, Stauffer JR Jr (eds) Distribution, biology, and management of exotic fishes. Johns Hopkins University Press, Baltimore, MD, p 233-261

Kathman RD, Brinkhurst RO (1998) Guide to the freshwater oligochaetes of North America. Aquatic Resources Center, College Grove, TN

Kent ML, Whitaker DJ, Margolis L (1993) Transmission of Myxobolus arcticus Pugachev \& Khokhlov, 1979, a myxosporean parasite of Pacific salmon, via a triactinomyxon from the aquatic oligochaete Stylodrilus heringianus (Lumbriculidae). Can J Zool 71:1207-1211

Kent ML, Margolis L, Corliss JO (1994) The demise of a class of protists: taxonomic and nomenclatural revisions proposed for the protist phylum Myxozoa Grassé, 1970. Can J Zool 72:932-937

Kent ML, Andree KB, Bartholomew JL, El-Matbouli M and 12 others (2001) Recent advances in our knowledge of the Myxozoa. J Eukaryot Microbiol 48:395-413

Lom J, McGeorge J, Feist SW, Morris D, Adams A (1997) Guidelines for the uniform characterisation of the actinosporean stages of parasites of the phylum Myxozoa. Dis Aquat Org 30:1-9

Lowers JM, Bartholomew JL (2003) Detection of myxozoan parasites in oligochaetes imported as food for ornamental fish. J Parasitol 89:84-91

Lowers JM, Lorz H, Bartholomew JL (2000) Potential for introduction of myxozoans via importation of oligochaetes as food for ornamental fish. In: Sixth Annual Whirling Disease Symposium February 3 \& 4 Coeur d'Alene, ID, p 35-36

Marquès A (1984) Contribution à la connaissance des Actinomyxidies: ultrastructure, cycle biologique, systématique. PhD thesis, Université des Sciences et Techniques du Languedoc, Montpellier

Oumouna M, Hallett SL, Hoffmann RW, El-Matbouli M (2003) Seasonal occurrence of actinosporeans (Myxozoa) and oligochaetes (Annelida) at a trout hatchery in Bavaria, Germany. Parasitol Res 89:170-184

Özer A, Wootten R, Shinn AP (2002) Survey of actinosporean types (Myxozoa) belonging to 7 collective groups found in a freshwater salmon farm in Northern Scotland. Folia Parasitol (České Budějovice) 49:189-210

Rácz OZ, Timm T (2002) First report on the occurrence of actinosporean stages of fish myxosporeans (Myxozoa, Myxosporea) in Estonia. Acta Parasitol 47:190-195

Raftos DA, Cooper EL (1990) Diseases of Annelida. In: Kinne O (ed) Diseases of marine animals, Vol 3. Biologische Anstalt Helgoland, Hamburg, p 229-243

Roubal FR, Hallett SL, Lester RJG (1997) First record of triactinomyxon actinosporean in marine oligochaete. Bull Eur Assoc Fish Pathol 17:83-85

Shotts EB Jr, Gratzek JB (1984) Bacteria, parasites, and viruses of aquarium fish and their shipping waters. In: Courtenay WR Jr, Stauffer JR Jr (eds) Distribution, biology, and management of exotic fishes. Johns Hopkins University Press, Baltimore, MD, p 215-232

Székely C, Molnár K, Eszterbauer E, Baska F (1999) Experimental detection of the actinospores of Myxobolus pseudodispar (Myxosporea: Myxobolidae) in oligochaete alternate hosts. Dis Aquat Org 38:219-224

Székely C, Rácz O, Molnár K, Eszterbauer E (2002a) Development of Myxobolus macrocapsularis (Myxosporea: Myxobolidae) in an oligochaete alternate host, Tubifex tubifex. Dis Aquat Org 48:117-123

Székely C, Urawa S, Yokoyama H (2002b) Occurrence of actinosporean stages of myxosporeans in an inflow brook of a salmon hatchery in the Mena River System, Hokkaido, Japan. Dis Aquat Org 49:153-160

Timm T (1999) A guide to the Estonian Annelida. Teaduste Akadeemia Kirjastus, Estonian Academy Publishers, Tallinn Wagner EJ, Smith M, Arndt R, Roberts DW (2003) Physical 
and chemical effects on viability of the Myxobolus cerebralis triactinomyxon. Dis Aquat Org 53:133-142

Wolf K, Markiw ME (1984) Biology contravenes taxonomy in the Myxozoa: new discoveries show alternation of invertebrate and vertebrate hosts. Science 225:1449-1452

Xiao C, Desser SS (1998a) Actinosporean stages of myxozoan parasites of oligochaetes from Lake Sasajewun, Algonquin Park, Ontario: new forms of triactinomyxon and raabeia. J Parasitol 84:998-1009

Editorial responsibility: Wolfgang Körting,

Hannover, Germany
Xiao C, Desser SS (1998b) Actinosporean stages of myxozoan parasites of oligochaetes from Lake Sasajewun, Algonquin Park, Ontario: new forms of echinactomyxon, neoactinomyxum, aurantiactinomyxon, guyenotia, synactinomyxon and antonactinomyxon. J Parasitol 84:1010-1019

Xiao C, Desser SS (2000) Molecular characterization of myxozoan parasites from Lake Sasajewun, Algonquin Park, Ontario, by riboprinting. J Eukaryot Microbiol 47:5-89

Submitted: August 8, 2004; Accepted: January 5, 2005 Proofs received from author(s): June 20, 2005 